\title{
Children’s Cognitive Development in Social Vulnerability: An Interventional Experience*
}

\author{
María Cristina Richaud, Vanessa Arán Filippetti \\ Interdisciplinary Research Center in Mathematical and Experimental Psychology (CIIPME), National Council of Scientific and \\ Technical Research (CONICET), Buenos Aires, Argentina
}

\begin{abstract}
This work presents the information resulting from our studies regarding the effects of socioeconomic status (SES) on executive functions (EF). In the same context, we set out a proposal for cognitive intervention to strengthen cognitive resources in the school setting. We conclude that the differences in the cognitive executive system associated with SES are the consequence of the interaction of specific socioeconomic variables and a cognitive impulsivity, as well as lesser linguistic abilities that act as mediating variables in explaining the lower executive achievement associated with SES. Understanding the possible causal socioeconomic indicators and those mediating cognitive variables enables the design of intervention strategies and planning educational and social policies tending to reduce the impact of poverty on cognitive development.
\end{abstract}

Keywords: cognitive development, executive functions, social vulnerability, children

The environment in which the nervous system develops influences the brain's structure and its functioning. The experiences that are frequently repeated — whether positive or negative-have impact on the way that the brain is organized. Strengthening of the synaptic elements is achieved through functional validation, in such a way that the brain connects in order to compare the needs in its surroundings (Andersen, 2003). If the environmental in which the child lives does not provide optimal conditions for their development (i.e., nutrition, sensory stimulation, health of the mother, mother/child attachment, etc.), neither the quantity nor the variety of neural pathways will be adequate.

There are various environmental factors, beyond nutrition, that can affect the process of brain development, but one of the most crucial is environmental stressors, which impact the biology of the brain, mainly by influencing the body's hormone function (Larson, Gunnar, \& Hertsgaard, 1991; Lewis \& Thomas, 1990). Toxic stress during the first years of life can affect the development of neural pathways and hormonal systems. Studies undertaken with both humans and animals show that elevated levels of cortisol over a prolonged period can alter the function of the neural system and change the architecture of regions of the brain that are essential for learning and memory. Furthermore, the circuits involved in the regulation of emotions are highly interactive with those associated with EF (such as planning and decision-making), which are intimately involved in the

\footnotetext{
* This work was financed by the National Council of Scientific and Technical Research (CONICET).

María Cristina Richaud, Ph.D., Interdisciplinary Research Center in Mathematical and Experimental Psychology (CIIPME)-CONICET. Email: mrichaud@conicet.gov.ar

Vanessa Arán Filippetti, Ph.D., Interdisciplinary Research Center in Mathematical and Experimental Psychology (CIIPME)-CONICET. Email: vanearan@gmail.com
} 
development of abilities for problem-solving (Posner \& Rothbart, 2000). In terms of basic brain function, emotions sustain EF when they are properly regulated, but interfere with attention and decision-making when they are poorly controlled (Bush, Luu, \& Posner, 2000; Damasio, 1999; Davis, 1992; LeDoux, 1996; Shonkoff \& Phillips, 2000).

A brain area that is particularly sensitive to the environmental context is the prefrontal cortex (PFC). Experimental models with animals have shown that the PFC is sensitive to a wide variety of factors, in the prenatal as well as the perinatal and postnatal periods. Prenatal stress (Fride \& Weinstock, 1988), perinatal anoxia and the postnatal social environment, create changes in the dopaminergic system and the development of the PFC (Sullivan \& Brake, 2003).

This has brought about copious amount of research in recent years analyzing the effects of SES on cognitive development, emphasizing the study of EF. EF is a construct that encompasses three different but related cognitive processes: (1) working memory, (2) cognitive flexibility, and (3) inhibition (Miyake et al., 2000). While various definitions and models have been proposed (see, e.g., Barkley, 1997; Goldberg, 2001; Lezak, 1995; Stuss \& Benson, 1986), in general there is consensus about define them as higher-order cognitive processes, given that they have control over more automatic cognitive processes, inhibiting irrelevant stimuli, manipulating online information and regulating cognitive, emotional and/or behavior activities towards the execution of a goal (Arán Filippetti \& López, 2014). Given that the PFC and the EF follow a postnatal course of development (Diamond, 2002; Fuster, 2002), early life experience-both positive and negative—can influence their development.

In the present work, we provide a synthesis of our main studies regarding the effects of SES on cognitive task performance and present an interventional proposal for strengthening cognitive resources through daily curricular tasks.

\section{Cognitive Studies Associated With SES: An Integration of Our Main Results}

\section{Cognitive Profiles Associated With SES}

In our studies, we have found cognitive differences associated with SES in terms of intellectual abilities (Arán Filippetti \& Richaud de Minzi, 2012), language and attention (Arán Filippetti, 2012), EF (Arán Filippetti, 2011; Arán Filippetti \& Richaud de Minzi, 2012) and reflective-impulsive cognitive style (Arán Filippetti \& Richaud de Minzi, 2011; Arán Filippetti \& Richaud de Minzi, 2012). More specifically, with regard to the effect of SES on EF, we found that low-SES children obtain lower scores than middle-SES children on tasks that evaluate working memory, reactive and spontaneous cognitive flexibility, inhibition and planning abilities (Arán Filippetti \& Richaud de Minzi, 2012). It is important to emphasize that while performance in low-SES children was inferior to that of middle-SES children, we found a gradual increase in both according to age, rather than a permanent and stable developmental deficit. This suggests that delays EF maturation processes are mainly due to a lack of environmental stimulation, rather than a permanent deficit in the mechanisms necessary for developing these functions (Arán Filippetti, 2013).

Interestingly, we have found that SES effects on cognitive development vary in function of the cognitive area; when analyzing the percentage of explained variance, we observe that the differences in performance related to SES were in the 70\%-80\% range for intellectual abilities, $21 \%-70 \%$ for EFs (Arán Filippetti \& Richaud de Minzi, 2012), 45\% for cognitive impulsivity and 14\%-37\% for different attentional tasks (i.e., selective attention, inhibitory control and concentration) (Arán Filippetti, 2012). This data suggest that a high 
percentage of variance in these cognitive processes would be explained by the effect of SES, though it is necessary to take into account that other sources of variability exist that could explain these differences.

Taken together, these results are consistent with previous studies that have demonstrated that Low-SES children have lower performance when it comes to: (1) intellectual abilities (Ramey \& Campbell, 1991; Smith, Brooks-Gunn, \& Klebanov, 1997); (2) the level of vocabulary achieved (Hart \& Risley, 1995; Hoff, 2003; Pan, Rowe, Singer, \& Snow, 2005) and language comprehension (Noble, Norman, \& Farah, 2005; Noble, McCandliss \& Farah, 2007); (3) attentional processes (Mezzacappa, 2004; Stevens, Lauinger, \& Neville, 2009); and in (4) diverse tasks that values executive functioning (Farah et al., 2006; Noble et al., 2005; Noble et al., 2007).

\section{Predictive and Mediating Variables}

With respect to the socioeconomic indicators that predict cognitive performance, we found that of the different variables included in our studies (i.e., occupational level, mother's educational level, family income and housing conditions), only the mother's educational level (MEL) and housing conditions (HC) were significant predictors of performance in tasks that rely on EF (Arán Filippetti \& Richaud de Minzi, 2012), language and attention (Arán Filippetti, 2012). For all of the analyzed cognitive functions, MEL was the principal predictor and explained a high percentage of the variance ( $r^{2}$ from 0.11 to 0.59 ). This association would be independent from the child's culture and mother tongue, as it has been also demonstrated in English-speaking families (Noble et al., 2005; Noble et al., 2007) as well as Finnish speakers (Klenberg, Korkman, \& Lahti-Nuuttila, 2001) and Spanish speakers (Ardila, Rosselli, Matute, \& Guajardo, 2005; Matute Villaseñor, Sanz Martín, Gumá Díaz, Rosselli, \& Ardila, 2009).

Given its importance for designing intervention strategies, we have also analyzed the possible mediating cognitive variables in the association between SES and cognitive performance. Our hypothesis was that language comprehension (see Arán Filippetti, 2012) and cognitive impulsivity (see Arán Filippetti \& Richaud de Minzi, 2012) might be mediating variables in explaining the lower performance in executive tasks associated with SES. In the first place, and in line with the findings of Noble et al. (2007), we found that language partially mediate the association between SES and cognitive performance (Arán Filippetti, 2012). Additionally, in line with our hypothesis, we found that cognitive impulsivity, and not IQ levels, mediates the relationship between SES and executive functioning (Arán Filippetti \& Richaud de Minzi, 2012). In this way, we conclude that the difference in the executive functioning associated with SES could be due to a lack of cognitive stimulation and a lesser development of interior language, which derives in a greater cognitive impulsivity and a tendency to respond hastily, causing a cascade of lower performance in EFs. One interesting aspect in favor of this hypothesis is the abundant empirical evidence indicating that cognitive impulsivity is susceptible to change and that reflective abilities can be trained (see, e.g., Arán Filippetti \& Richaud de Minzi, 2011; Bornas Agustí, Servera Barceló, Serra Mates, \& Escudero López, 1990; Gargallo, 1993a, 1993b). As such, if this is one of the mechanisms through which SES leads to lower executive performance, this low performance can be reverted and this is where intervention strategies can be rethought.

\section{Interventions to Strengthen Cognitive Resources}

In recent years, various programs have been implemented with the goal of strengthening cognitive resources related to school learning. Among these, are for example, (1) “The Abecedarian Program” (Barnett \& Masse, 2007; Campbell et al., 2008; Ramey \& Campbell, 1991); (2) “The Perry Preschool Program” (Belfield, Nores, Barnett, \& Schweinhart, 2006; Weikart, 1998); and (3) “The Child-Parent Center” (CPC) Program 
(Reynolds \& Temple, 1998; Reynolds, Temple, Robertson, \& Mann 2001; Reynolds et al., 2007). Following the application of these programs, it has been demonstrated that it is feasible to improve cognitive ability among Low SES students, after not lengthy interventions. In the specific area of EF, the "Tools of the mind" program developed by Bodrova and Leong (1996) merits special mention. This program, based on the theories of Luria (1961) and Vigotsky (1979), has proven to be effective in promoting self-control and the development of EF in school-aged children. Studies such as those undertaken by Barnett et al. (2008) and Diamond, Barnett, Thomas, and Munro (2007) have applied this program, demonstrating its effectiveness at improving executive performance among Low-SES children.

In Argentina, intervention programs have also been implemented adapted to the school curriculum, with the objective of strengthening cognitive abilities related to school learning. As such, for example, in the context of a project called "Developing resilience in children from at risk environments in extreme poverty", which is a comprehensive program aimed at strengthening not only cognitive resources, but also socio-emotional resources, carried out in the school setting and adapted to the curriculum, we have undertaken various studies that provide evidence of improved cognitive performance through systematized training (Ghiglione, Arán Filippetti, Manucci, \& Apaz, 2011; Arán Filippetti \& Richaud de Minzi, 2012). Our intervention proposal was implemented based in two main areas:

(1) Primary Intervention consists of working directly with children in their school setting to stimulate and strengthen the development of cognitive resources. This intervention was undertaken by specialized professionals (i.e., psychopedaogogues and psychologists) in conjunction with the teacher in each respective classroom. The sessions took place 3 to 4 times per week for 30 minutes each. During the implementation of the cognitive strategies, the leaders guided the development of the activities using cognitive modeling and verbal self-instruction as basic strategies (see Meichembaum \& Goodman, 1971), which favor the use of private speech that allows the regulation of behavior and promotes self-management as a consequence. Specific activities were also designed to stimulate attentional, memory and EF, promoting the use of scanning and visual discrimination strategies (e.g., looking for shapes similar to a model; selective attention exercises and looking for similarities and differences in shapes) (Egeland, 1974; Meichenbaum \& Goodman, 1971) and analytical strategies similar to those of the Matching Familiar Figures Test paradigm (Kagan, 1965), to strengthen self-regulation and cognitive reflexivity.

(2) Secondary Intervention consists of working with teachers in educational institutions. The teachers received training on designing new cognitive strategies based on the above-mentioned techniques. The objective of the intervention was for the teachers to stimulate cognitive resources, while at the same time delivering the curricular content for the school term. The training was delivered to the teachers in the school setting in weekly meeting of 3 hours in length. Intervention notebooks were developed to stimulate basic cognitive function adapted to the school setting. Given that the final objective was to undertake an intervention with ecological criteria that would adapt to the needs of the classroom and the education task, the exercise notebooks were offered as a model and the trainers worked along with the teachers to design their own strategies according to the base exercises, but adapted to the school curriculum. Table 1 presents an example of an activity undertaken by a teacher in order to strengthen $\mathrm{EF}$, based on an activity proposed by the intervention program.

\footnotetext{
1 The project is lead by Dra. María Cristina Richaud de Minzi and was financed by the Ministry of Science, Technology and Productive Innovation (PICT 03/14064).
} 
Table 1

Example of an Activity Carried out in the School Setting

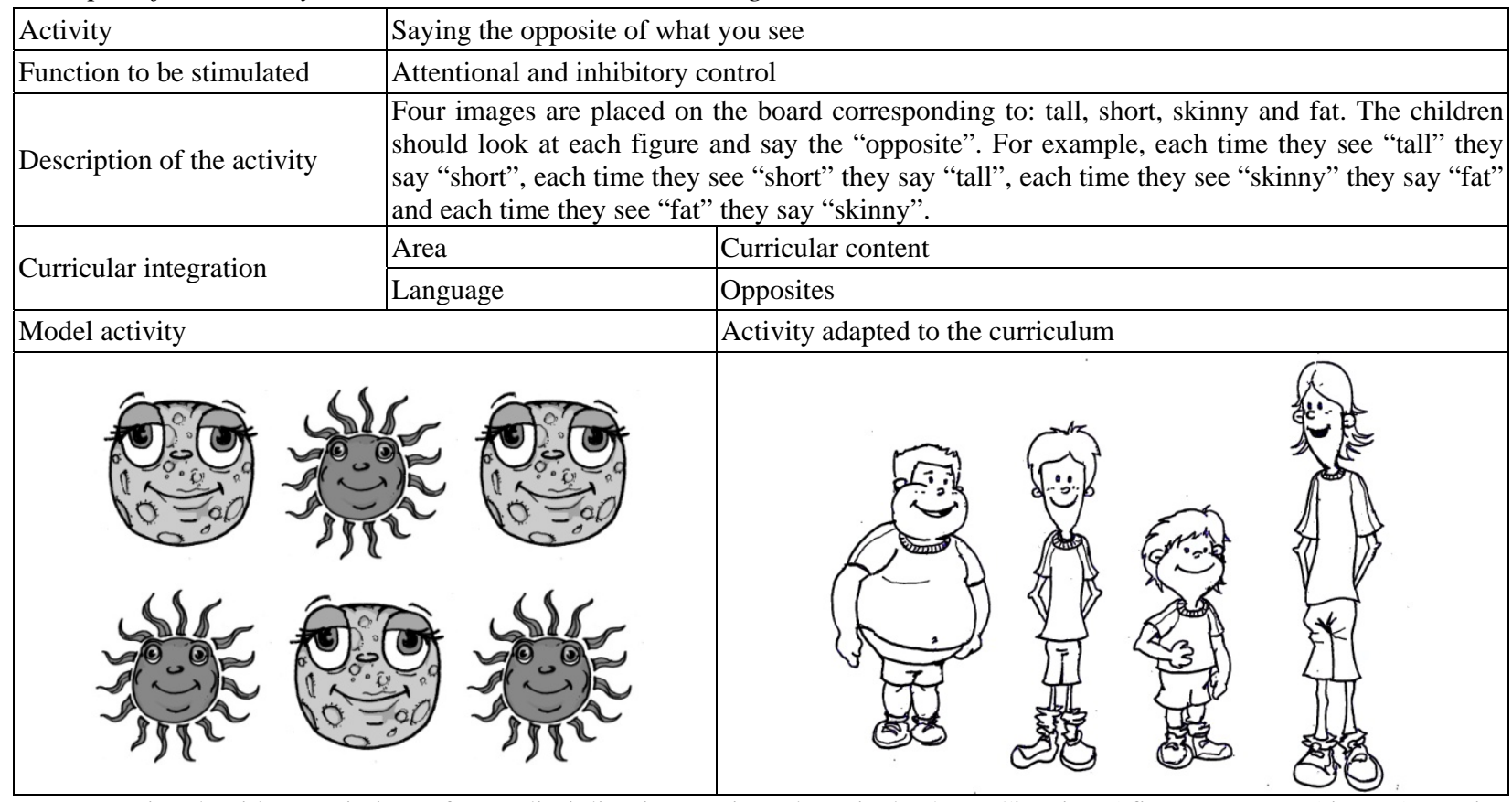

Note. Reprinted with permission of Interdisciplinaria. Revista de Psicología y Ciencias Afines. Buenos Aires, Argentina (Ghiglione et al., 2011).

After applying this intervention program, we have found an improvement in executive task performance and a reduction in cognitive impulsivity (Arán Filippetti \& Richaud de Minzi, 2011; Ghiglione et al., 2011). Specifically, it was found that after the intervention, the children got higher scores on planning ability measures $(M$ pretest $=14.09 ; S D$ pretest $=6.29 ; M$ post-test $=20.87, S D$ post-test $=4.20)$ and demonstrated less cognitive impulsivity $(M$ pretest $=1.75, S D$ pretest $=1.38 ; M$ post-test $=-0.89, S D$ post-test $=1.89)($ Arán Filippetti $\&$ Richaud de Minzi, 2011).

\section{Conclusions}

The results of our studies show that low-SES children show lower performance of tasks that evaluate EF, intellectual abilities, attention and language, in comparison with middle-SES children. We also found that socioeconomic indicators are selectively related to cognitive functioning, with MEL and HC being the most predictive variables. This suggests, as consistent with studies done by Noble et al. (2007) and Farah et al. (2008), that there is dissociation in the relationship between the environmental variables and cognitive development. Finally, cognitive variables such as cognitive impulsivity and linguistic abilities mediate the association between SES and performance on tasks that evaluate EF.

We believe that this cognitive impulsivity is due in part to a lesser development of interior language or a use that is inadequate for the self-regulation of behavior. This is manifested in a lack of cognitive reflexivity. These processes are likely affected as a consequence of the lack of stimulation and social interaction. Several authors have pointed out that the quality and quantity of private speech employed by children depends on their prior social interaction with adults (Berk \& Spuhl, 1995; Winsler, Diaz, McCarthy, Atencio, \& Chabay, 1999). At the same time, the private speech that children used is related to their current and future performance on 
different tasks (Winsler, Díaz, \& Montero, 1997). Insomuch as self-regulation is crucial for performance in executive functioning and non-executive tasks, it can explain the differences in executive task performance according to SES.

Other possible mediating variables associated with the socioeconomic variables would include: (1) less cognitive stimulation at home; (2) less resources for developmental stimulation; (3) less adult external regulation; and (4) exposure to a hostile environmental with less social interaction and more exposure to stress factors, among others. Besides, the effect of the neighborhood (Brooks-Gunn, Duncan, \& Aber, 1997; Brooks-Gunn, Duncan, Klebanov, \& Sealand, 1993) and characteristics of the educational institution (Sirin, 2005) might also act as mediators between SES and cognitive performance.

Based on the results synthesized in this study, we conclude that low-SES children would not present a primary executive function deficit, but rather a difficulty to perform executive tasks in an effective way, given their cognitive impulsivity and lack of specific stimulation for the development of EF. Thus, for the development of these higher-order cognitive processes, exposure to certain activities that demand cognitive functioning would be required and an adequate verbal external regulation which favors the effective use of private speech. In agreement with Dowsett and Livesey (2000), it is possible that reiterated exposure to tasks that demand reflexivity may accelerate the acquisition of complex rules and increment control over one's thoughts and actions.

It is on this point, that Vigotsky's work acquires special relevance for work with low-SES children, because its puts teaching at the forefront of the child's knowledge appropriation process, and from a historical-cultural perspective, the role of natural and social aspects of cognitive development. That is to say that, on one hand, this theory allows one to explain cognitive differences among children in culturally impoverished settings, while on the other hand, given the necessity of intervening on behalf of this population of at-risk children, the concepts of "zone of proximate development", "scaffolding" and "private speech" acquire special relevance given that they point to the possibility of working on an interpersonal and social plane in order to achieve internal mental transformation, favoring self-regulation and cognitive development among children.

The fact that performance on EF tasks improves significantly through the use of systematic intervention strategies brings us to rethink the critical role of experience in children's development. In the specific case of EF, according to Dowsett and Livesey (2000), there are a great number of studies on maturation effects, but there are still few that analyze the effects of experience on the development of these processes.

In synthesis, the studies suggest that intensive interventions with high-risk children have lasting effects on cognitive, emotional and social development (Campbell, Pungello, Miller-Johnson, Burchinal, \& Ramey, 2001; Shonkoff \& Phillips, 2000) and that in reducing the impact of poverty on children, the most important interventions are those that occur in early childhood (Brooks-Gunn \& Duncan, 1997). At the same time, these interventions must be continued over time. Taking into account the role of experience in socio-emotional and cognitive development in children, it is important to mention that maturational delays in impoverished children in these aspects, though reversible, unless action is taken to overcome them, can be perpetuated over time, altering the dynamics of the brain in a more permanent way. Thus, taking into account that brain development continues throughout adolescence (Diamond, 2002), we deem it important provide interventions for high-risk populations, taking advantage of the windows of opportunity offered by the process of brain development (Richaud de Minzi, 2008). 


\section{References}

Andersen, S. L. (2003). Trajectories of brain development: Point of vulnerability or window of opportunity? Neuroscience and Biobehavioral Reviews, 27, 3-18.

Arán Filippetti, V., \& López, M. B. (2014). The role of executive functions in academic competences: An analytical review (pp. 305-322). In K. P. Bennett (Ed.), Executive functioning: Role in early learning processes, impairments in neurological disorders and impact of cognitive behavior therapy (pp. 305-322). New York: Nova Science Publishers, Inc..

Arán Filippetti, V., \& Richaud de Minzi, M. C. (2011). Efectos de un programa de intervención para aumentar la reflexividad y la planificación en un ámbito escolar de alto riesgo por pobreza. Universitas Psychologica, 10, 341-354.

Aran Filippetti, V., \& Richaud de Minzi, M. C. (2012). A structural analysis of executive functions and socioeconomic status in school-age children: Cognitive factors as effect mediators. The Journal of Genetic Psychology, 173, 393-416.

Arán Filippetti, V. (2011). Funciones ejecutivas en niños escolarizados: efectos de la edad y del estrato socioeconómico. Avances en Psicología Latinoamericana, 29, 98-113.

Arán Filippetti, V. (2012). Estrato socioeconómico y habilidades cognitivas en niños escolarizados: Variables predictoras y mediadoras. Psykhe, 21, 3-20.

Arán-Filippetti, V. (2013). Structure and invariance of executive functioning tasks across socioeconomic status: Evidence from spanish-speaking children. The Spanish Journal of Psychology, 16, 1-15.

Ardila, A., Rosselli, M., Matute, E., \& Guajardo, S. (2005). The influence of the parents' educational level on the development of executive functions. Developmental Neuropsychology, 28, 539-560.

Barnett, W. S., Jung, K., Yarosz, D. J., Thomas, J., Hornbeck, A., Stechuk, R., et al. (2008). Educational effects of the tools of the mind curriculum: A randomized trial. Early Childhood Research Quarterly, 23, 299-313.

Barnett, W., \& Masse, L. (2007). Comparative benefit-cost analysis of the Abecedarian program and its policy implications. Economics of Education Review, 26, 113-125.

Barkley, R. A. (1997). Behavioural inhibition, sustained attention, and executive functions: Constructing a unifying theory of AD/HD. Psychological Bulletin, 121, 65-94.

Belfield, C., Nores, M., Barnett, S., \& Schweinhart, L. (2006). The High/Scope Perry Preschool Program: Cost benefit analysis using data from the age-40 follow-up. The Journal of Human Resources, XLI, 162-190.

Berk, L. E., \& Spuhl, S. T. (1995). Maternal interaction, private speech, and task performance in preschool children. Early Childhood Research Quarterly, 10, 145-169.

Bodrova, E., \& Leong, D. J. (2007). Tools of the mind: The Vygotskian approach to early childhood education (2nd ed, pp. 341-354). Upper Saddle River, N.J.: Prentice-Hall.

Bornas Agustí, X., Servera Barceló, M., Serra Mates, F., \& Escudero López, J. T. (1990). El tratamiento de la impulsividad infantil: Autoinstrucciones versus solución de problemas. Estudios de Psicología, 43-44, 61-71.

Brooks-Gunn, J., \& Duncan, G. J. (1997). The effects of poverty on children. The Future of Children, 7, 55-71.

Brooks-Gunn, J., Duncan, G. J., \& Aber, J. A. (1997). Neighborhood poverty: Vol. I: Context and consequences for children. New York: Russell Sage Found.

Brooks-Gunn, J., Duncan, G. J., Klebanov, P. K., \& Sealand, N. (1993). Do neighborhoods influence child and adolescent development? American Journal of Sociology, 99, 353-395.

Bush, G., Luu, P., \& Posner, M. I. (2000). Cognitive and emotional influences in anterior cingulate cortex. Trends in Cognitive Sciences, 4, 215-222.

Damasio, A. R. (1999). The feeling of what happens: Body and emotion in the making of consciousness. New York: Harcourt Brace.

Davis, M. (1992). The role of the amygdala in conditioned fear. In J. P. Aggleton (Ed.), The amygdala: Neurobiological aspects of emotion, memory, and mental dysfunction (pp. 255-306). New York: Wiley-Liss.

Diamond, A. (2002). Normal development of prefrontal cortex from birth to young adulthood: Cognitive functions, anatomy, and biochemistry. In D. T. Stuss, \& R. T. Knight (Eds.), Principles of frontal lobe function (pp. 466-503). London: Oxford University Press.

Diamond, A., Barnett, W. S., Thomas, J., \& Munro, S. (2007). Preschool program improves cognitive control. Science, 318, 1387-1388.

Dowsett, S. M., \& Livesey, D. J. (2000). The development of inhibitory control in preschool children: Effects of "executive skills" training. Developmental Psychobiology, 36, 161-174. 
Campbell, F. A., Pungello, E. P., Miller-Johnson, S., Burchinal, M., \& Ramey, C. T. (2001). The development of cognitive and academic abilities: Growth curves from an early childhood educational experiment. Developmental Psychology, 37, $231-242$.

Campbell, F. A., Wasik, B., Pungello, E. P., Burchinal, M. R., Barbarin, O. A., Kainz, K., Sparling, J., \& Ramey, C. T. (2008). Young adult outcomes of the Abecedarian and care early childhood educational interventions. Early Childhood Research Quarterly, 23, 452-466.

Egeland, B. (1974). Training impulsive children in the use of more efficient scanning techniques. Child Development, 45, $165-171$.

Farah, M. J., Shera, D. M., Savage, J. H., Betancourt, L., Giannetta, J. M., Brodsky, N. L., et al. (2006). Childhood poverty: Specific associations with neurocognitive development. Brain Research, 1110, 166-174.

Farah, M. J., Betancourt, L., Shera, D. M., Savage, J. H., Giannetta, J. M., Brodsky, N. L., Malmud, E. K., \& Hurt, H. (2008). Environmental stimulation, parental nurturance and cognitive development in humans. Developmental Science, 11, $793-801$.

Fride, E., \& Weinstock, M. (1988). Prenatal stress increases anxiety related behavior and alters cerebral lateralization of dopamine activity. Life Sciences, 42, 1059-1065.

Fuster, J. M. (2002). Frontal lobe and cognitive development. Journal of Neurocytology, 31, 373-385.

Gargallo, L. B. (1993a). Es posible modificar la impulsividad en el aula? Programas de acción educativa. Revista de Educación, 301, 245-268.

Gargallo, B. (1993b). Basic variables in reflection-impulsivity: A training programme to increase reflectivity. European Journal of Psychology of Education, 8, 151-167.

Ghiglione, M. E., Arán Filippetti, V., Manucci, V., \& Apaz, A. (2011). Programa de intervención, para fortalecer funciones cognitivas y lingüísticas, adaptado al currículo escolar en niños en riesgo por pobreza. Interdisciplinaria, 28, 17-36.

Diamond, A., Barnett, W. S., Thomas, J., \& Munro, S. (2007). Preschool program improves cognitive control. Science, 318, 1387-1388.

Goldberg, E. (2001). The executive brain: Frontal lobes and the civilized mind. New York: Oxford University Press.

Hart, B., \& Risley, T. R. (1995). Meaningful differences in the everyday experiences of young American children. Baltimore, M.D.: Paul H. Brookes.

Hoff, E. (2003). The specificity of environmental influence: Socioeconomic status affects early vocabulary development via maternal speech. Child Development, 74, 1368-1378.

Kagan, J. (1965). Matching familiar figures test. Cambridge: Hardvard University.

Klenberg, L., Korkman, M., \& Lahti-Nuuttila, P. (2001). Differential development of attention and executive functions in 3- to 12-year-old Finnish children. Developmental Neuropsychology, 20, 407-428.

Larson, M., Gunnar, M., \& Hertzgaard, L. (1991). The effects of morning naps, car trips, and maternal separation on adrenocortical activity in human infants. Child Development, 62, 362-372.

LeDoux, J. (1996). The emotional brain. New York: Simon \& Schuster.

Lewis, M., \& Thomas, D. (1990). Cortisol release in infants in response to inoculation. Child Development, 61, 50-59.

Lezak, M. (1995). Neuropsychological assessment (3 ed.). New York: Oxford University Press.

Luria, A. R. (1961). The role of speech and the regulation of normal and abnormal behaviors. Nueva York: Liveright.

Matute Villaseñor, E., Sanz Martín, A., Gumá Díaz, E., Rosselli, M., \& Ardila, A. (2009). Influencia del nivel educativo de los padres, el tipo de escuela y el sexo en el desarrollo de la atención y la memoria. Revista Latinoamericana de Psicología, 41, 257-276.

Meichenbaum, D. H., \& Goodman, J. (1971). Training impulsive children to talk to themselves: A means of developing self-control. Journal of Abnormal Psychology, 77, 115-126.

Mezzacappa, E. (2004). Alerting, orienting, and executive attention: Developmental properties and sociodemographic correlates in an epidemiological sample of young, urban children. Child Development, 75, 1373-1386.

Miyake, A., Friedman, N. P., Emerson, M. J., Witzki, A. H., Howerter, A., \& Wager, T. D. (2000). The unity and diversity of executive functions and their contributions to complex "Frontal Lobe" tasks: A latent variable analysis. Cognitive Psychology, 41, 49-100.

Noble, K. G., Norman, M. F., \& Farah, M. J. (2005). Neurocognitive correlates of socioeconomic status in kindergarten children. Developmental Science, 8, 74-87.

Noble, K. G., McCandliss, B. D., \& Farah, M. J. (2007). Socioeconomic gradients predict individual differences in neurocognitive abilities. Developmental Science, 10, 464-480.

Pan, B. A., Rowe, M. L., Singer, J. D., \& Snow, C. E. (2005). Maternal correlates of growth in toddler vocabulary production in low-income families. Child Development, 76, 763-782. 
Posner, M. I., \& Rothbart, M. K. (2000). Developing mechanisms of self-regulation. Development and Psychopathology, 12, 427-441.

Ramey, C. T., \& Campbell, F. A. (1991). Poverty, early childhood education, and academic competence: The Abecedarian experience. In A. C. Huston (Ed.), Children reared in poverty: Child development and public policy (pp. 190-221). New York: Cambridge University Press.

Reynolds, A. J., \& Temple, J. A. (1998). Extended early childhood intervention and school achievement: Age thirteen findings from the Chicago Longitudinal Study. Child Development, 69, 231-246.

Reynolds, A. J., Temple, J. A., Ou, S. R., Robertson, D. L., Mersky, J. P., Topitzes, J. W., \& Niles, M. D. (2007). Effects of a school-based, early childhood intervention on adult health and well-being: A 19-year follow-up of low-income families. Archives of Pediatric Adolescent Medicine, 161, 730-739.

Reynolds, A. J., Temple, J. A., Robertson, D. L., \& Mann, E. A. (2001). Long-term effects of an early childhood intervention on educational achievement and juvenile arrest: A 15-year follow-up of low-income children in public schools. JAMA: Journal of the American Medical Association, 285, 2339-2346.

Richaud de Minzi, M. C. (2008). How to reinforce psychological resources in children at risk by poverty. In M. C. Richaud de Minzi (Org.), Invited Symposium Development of Psychological and Biological Resources in Children at Risk, XXIX International Congress of Psychology, Berlin, Germany.

Sirin, S. R. (2005). Socioeconomic status and academic achievement: A meta-analytic review of research. Review of Educational Research, 75(3), 417-453.

Shonkoff, J. P., \& Phillips, D. A. (Eds.). (2000). From neurons to neighborhoods: The science of early child development. Washington, D.C.: National Academy Press.

Smith, J., Brooks-Gunn, J., \& Klebanov, P. (1997). Consequences of living in poverty for young children's cognitive and verbal ability and early school achievement. In G. Duncan, \& J. Brooks-Gunn (Eds.), Consequences of growing up poor (pp. 132-189). New York: Russell Sage Foundation.

Stevens, C., Lauinger, B., \& Neville, H. (2009). Differences in the neural mechanisms of selective attention in children from different socioeconomic backgrounds: An event related brain potential study. Developmental Science, 12, 634-646.

Stuss, D. T., \& Benson, D. F. (1986). The frontal lobes. New York: Raven Press.

Sullivan, R. M., \& Brake, W. G. (2003). What the rodent prefrontal cortex can teach us about attention-deficit/hyperactivity disorder: The critical role of early developmental events on prefrontal function. Behavioural Brain Research, 146, 43-55.

Vigotsky, L. S. (1979). El desarrollo de los procesos psicológicos superiores. Barcelona, España: Crítica.

Weikart, D. P. (1998). Changing early childhood development through educational intervention. Preventive Medicine, 27, 233-237.

Winsler, A., Diaz, R. M., McCarthy, E. M., Atencio, D. J., \& Chabay, L. A. (1999). Mother-child interaction, private speech, and task performance in preschool children with behavior problems. Journal of Child Psychology and Psychiatry, 40, 891-904.

Winsler, A., Diaz, R. M., \& Montero, I. (1997). The role of private speech in the transition from collaborative to independent task performance in young children. Early Childhood Research Quarterly, 12, 59-79. 